\title{
Mining in the twenty-first century and its world of work: Considerations for universities offering mining qualifications
}

\author{
Frederick Cawood $^{1 *}$ \\ ${ }^{1}$ Wits Mining Institute, University of the Witwatersrand, 3 Private Bag, 2050 Wits, South Africa
}

\begin{abstract}
The intelligent digital mine of the future will look very different to what we have today; it will be managed differently, have different skill-sets, and will be staffed by professions that do not exist today. While mining in the 20th century was about 'more' (more production, for example), the 21st century is about 'better' (safer production, for example). This article investigates this fundamental shift from 'more' to 'better' by examining how the current international trends affect mining and its world of work. There are clear indications that the future of work requires a re-evaluation of skills-sets, qualifications and certification thereof. Although this shift creates a problem for current mine occupations with outdated skills-sets, there are many new opportunities for those who update their skills and knowledge so that they remain (or become) relevant in a cross-industry 21 st century context. The approach followed in this article is an interpretation of how the fourth industrial revolution affects the world - and mining in particular - followed by a conceptual analysis of how it is shaping the future of work for mining. The fundamental learning content for a future-ready mining engineering graduate is then addressed. The findings of this article will benefit mining in general, but more particularly universities, skills providers and, most important, the youth who are preparing themselves for this world of work in mining.
\end{abstract}

\section{Introduction}

Mining remains an important and significant contributor to the global economy, especially for underdeveloped, resource-rich countries [1]. A growing mining sector is important for supplying raw materials for manufacturing, creating good jobs and stabilising the economy [2]. The earlier industrial revolutions were about "bigger" and "more". The result was the steady replacement of human muscle with machine power. Advancements in computing technologies enabled the machines not only to do more, but to perform better too. Surface mines today apply the concept of economies of scale extensively as a "solution" to the world's seemingly endless consumption needs. Fig. 1 illustrates the growing demand for mineral products from 1984 to 2017, which caused production to almost double over the period.

\footnotetext{
*Corresponding author: Frederick.Cawood@,wits.ac.za
} 


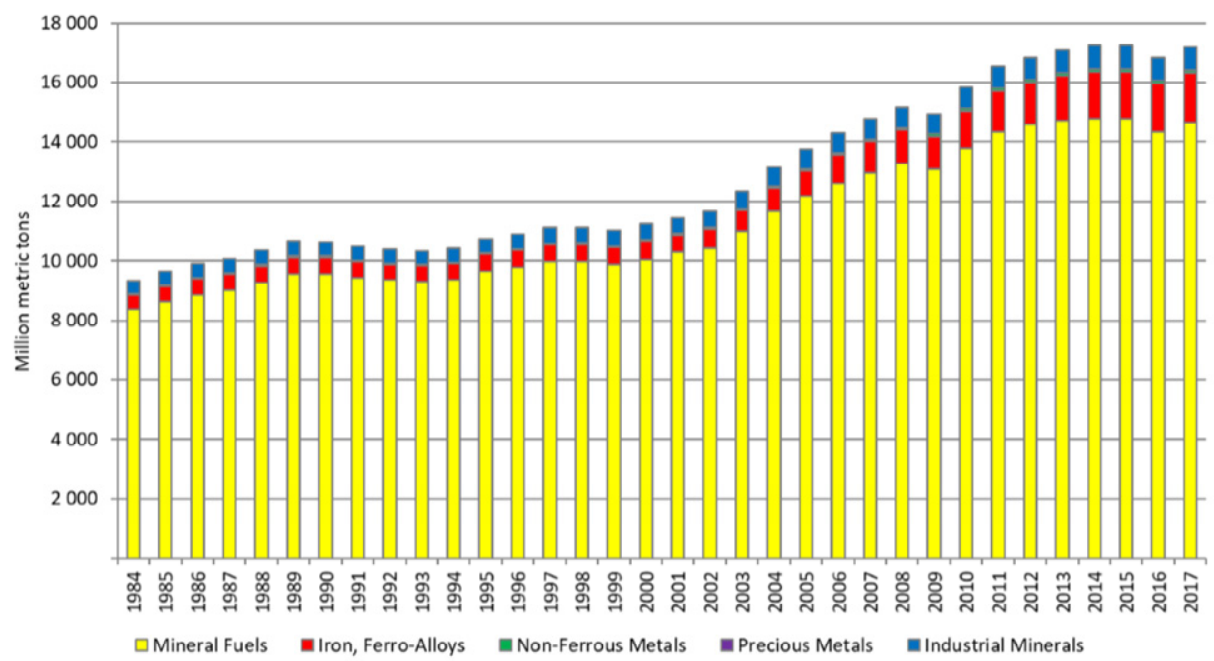

Fig. 1. World mining production $1984-2017$ by groups of minerals (without construction minerals, in millions of metric tonnes). Source: World Mining Data 2019.

The technologies of the fourth industrial revolution allow us to collect data on almost everything and anything at any point in time. This data should inform better decisions for a "better" future; better in the context of mining means safe and efficient - with less harm and more benefit for mining stakeholders and communities, leading to stakeholder trust. This vision of a better future also aligns with the ideals of the African Mining Vision [3]. This article investigates how the current trends affect mining and its world of work, with the objective of formulating a view on the impact on qualifications and skills.

Typical problems for developing countries include an inefficient and constrained educational system when updating programmes, as well as a general lack of university investment in technology and skills. Despite having qualifications, there are not enough jobs for graduates, causing them to become disillusioned with both the educational system and the mining industry. The perceived value proposition of relevant skills-sets and qualifications is that such qualifications will lead to jobs, responsible development of nonrenewable mineral resources, cost-effective and efficient implementation of new technology, and capable workers doing the right work safely and driving productivity to add value to the business. Most importantly, technological innovation becomes possible where there are enough graduates with the right qualifications.

This paper starts with a brief overview of mining in the early 21 st century, outlining the current issues and trends that are affecting mining. Although some thoughts are long-term, this article is targeting the immediate future - to find a practical way going forward from today. It continues with a discussion on the world of work for mining, which aims to determine the impact this world of work has on qualifications and skills for jobs. The paper ends with suggestions on how universities and skills providers can align their offerings with the future world of work for mining, to optimise their broader benefit.

\section{Mining in the 21st century}

The importance of mineral products to support a decent standard of living cannot be underplayed. In a 2013 address to the World Mining Congress on the role of mining in society, Cutifani observed: "Mining is not everything. But without mining, everything is nothing" [4]. Twenty years into the 21 st century is a long-enough duration to analyse 
current issues and trends for forecasting the immediate future. Table 1 is an update on an earlier study by the author [5].

Table 1. Current trends in mining and their impact on the future of mining.

\begin{tabular}{|c|c|}
\hline Trend & $\begin{array}{l}\text { Responses to influence the future which the trend is leading } \\
\text { to }\end{array}$ \\
\hline $\begin{array}{l}\text { Scarcity of (traditional) reserves and } \\
\text { search for (new) } 21 \text { st century metals }\end{array}$ & $\begin{array}{l}\text { Grow current reserve stocks. Search remote areas for new } \\
\text { reserves. Explore 'old' areas with new technologies. Search } \\
\text { world-wide for metals suitable for energy storage. }\end{array}$ \\
\hline $\begin{array}{l}\text { Mining is getting more remote and } \\
\text { underground mines will go deeper, } \\
\text { putting infrastructure under more } \\
\text { pressure }\end{array}$ & $\begin{array}{l}\text { Infrastructure in most of the developing world cannot cope, } \\
\text { resulting in less investment, poor growth and persistent } \\
\text { poverty in continents like Africa. }\end{array}$ \\
\hline $\begin{array}{l}\text { Persistent stakeholder attention to } \\
\text { mining and its profits }\end{array}$ & $\begin{array}{l}\text { Mining companies taking on some State delivery of services; } \\
\text { Strengthening of price and cost accounting systems }\end{array}$ \\
\hline $\begin{array}{l}\text { Shifting stakeholder expectations are } \\
\text { pushing resource nationalism to the } \\
\text { forefront (again) }\end{array}$ & $\begin{array}{l}\text { A new definition/understanding of what responsible mining, } \\
\text { license to practice and State's role/participation in mining } \\
\text { means in a difficult operating environment }\end{array}$ \\
\hline $\begin{array}{l}\text { Climate change and extreme weather } \\
\text { patterns are a growing, global concern }\end{array}$ & $\begin{array}{l}\text { New consumption pattern is starting - away from fossil } \\
\text { fuels. } \\
\text { Different future of energy. A re-imagined mining waste } \\
\text { strategy which includes zero carbon emissions and } \\
\text { monitoring of tailings storage facilities. }\end{array}$ \\
\hline $\begin{array}{l}\text { Capital for mining is becoming more } \\
\text { scarce because of risky investment } \\
\text { environment and price uncertainty }\end{array}$ & $\begin{array}{l}\text { Improve efficiency, risk management and pricing } \\
\text { arrangements through better response to demand patterns. }\end{array}$ \\
\hline $\begin{array}{l}\text { The continuous state of industry } \\
\text { transition makes it more difficult to } \\
\text { achieve plans }\end{array}$ & $\begin{array}{l}\text { Dynamic risk management practices taking account of mine, } \\
\text { market and global issues }\end{array}$ \\
\hline $\begin{array}{l}\text { Technology is disrupting markets, } \\
\text { mining, its future of work and } \\
\text { leadership }\end{array}$ & $\begin{array}{l}\text { A global mining pull for relevant technology and skills for } \\
\text { safe, intelligent mining and prospecting. A new future of } \\
\text { mining with a human-centered future of work. }\end{array}$ \\
\hline $\begin{array}{l}\text { More redundancy of old skills-sets } \\
\text { with growing need for new, relevant } \\
\text { skills }\end{array}$ & $\begin{array}{l}\text { New curricula for } 21 \text { st century skills-sets with re-skilling } \\
\text { and up-skilling at all levels, including leadership. } \\
\text { Reimagining qualifications, delivery and certification } \\
\text { thereof. }\end{array}$ \\
\hline
\end{tabular}

Assuming the trends are correct and will continue, they may lead to a future that can be described in the following terms:

- Minerals will remain important. Mining's value proposition to society is a steady supply of the raw materials that support decent living standards for world inhabitants. However, the growing demand for non-renewable mineral products is causing depletion of the available stock of mineral reserves. The quickest way to increase reserves is to extend the lives of current mines. Such growing of current reserve stocks can happen through achieving better efficiencies, mining "old" areas in new ways or re-mining waste and other stockpiles by using new technologies that have become available since the initial storage of what was then considered waste material. Alternatively, new stock must be found by exploring new areas frequently in remote locations. In addition to the "traditional" metals like copper, gold and iron ore that are required, there are also (new) 21 st century mining minerals that were added to the traditional list, like lithium, vanadium, nickel, graphite and cobalt. Some minerals coal, for example - will become less important while others, such as the metals required for storing (renewable) energy, will become more important over time.

- Mining will become more remote. This will cause continents like Africa, which have the right minerals in the right quantities and quality, to become potential future growth 
areas (on the assumption that their infrastructure can deal with such growth). The alternative is to explore remote locations and extend the depth of current mines, causing surface mines to go underground and underground mines to become deeper. Mining at depth also faces infrastructure problems. For example, long travel distances from surface to workplaces usually employs hybrid systems, which were not designed for extension of depths. In addition, ventilation systems may not cope with the challenges of providing cool, fresh air at depth, where heat increases. Both remote and deep mining possibilities require substantial investment to improve the poor and ageing infrastructure. Without such investment, it will not be possible for continents like Africa to respond to sudden market needs for more minerals. The result is that this poor elasticity to sudden market demand will result in companies located in poor infrastructure areas fetching lower prices over time, in turn causing stakeholders to miss mineral rents and associated benefits.

- Mining stakeholders expect mining companies to deliver benefit - even with poor or unavailable infrastructure. This causes persistent stakeholder attention to mining and its profits. In response, companies are strengthening their pricing and costing accounting systems in order to "defend" themselves when they are accused of 'cheating' on their tax returns through overstatement of costs and understatement of income. The demand for extended benefits from mining is further forcing mining companies to take on certain state responsibilities through delivery of services from their corporate social responsibility budgets. Despite this additional support to community stakeholders, the poverty gap is too wide for companies in low-income countries to bridge; this will cause poverty to remain an issue for mining in underdeveloped countries.

- Resource nationalism is on the rise. The expectation that mining companies must deliver benefit is difficult in the absence of agreement on what the benefits should be. This is causing expectations to shift as new issues confront communities. This dynamic is changing the traditional understanding of sustainability and sustainable development. With the general concern about the ability of planet Earth to sustain current consumption needs, sustainable development is becoming a core value for mining companies. This constantly affects the meaning of responsible mining and while there is no shared stakeholder vision for mining, resource nationalism will remain an issue. The mining industry adopted the UN Sustainable Development Goals [6] in working towards its interpretation, as documented in the ICMM Mining with Principles [7] initiative. Similarly, governments must define their role and responsibility to ensure that a license to practice becomes possible under evermore difficult conditions.

- Climate change is a global phenomenon, but the impact is local. Climate change has a multifaceted impact on mining and is disrupting the entire mining value chain. Extreme weather conditions and temperature rise can have severe outcomes for mines, such as flooding of workings, instability of tailings storage facilities and spreading of diseases like malaria in traditionally low-risk areas. The global attention on climate change is causing the global mining sector to re-imagine its energy and waste strategies. Mining companies have to find a solution to waste generation, including waste storage and management of waste facilities. In addition, a new consumption pattern has started - away from fossil fuels. For the first time in 200 years, the coal market is disrupted and the new future of energy is intricately linked to zero carbon emissions.

- Capital for mining is expensive and scarce. This is mostly because the mining sector is risky for investors and price uncertainty makes it difficult to predict earnings accurately. The additional burden on mining companies is affecting the cost of mining capital, so investors expect companies to compensate through a premium on returns and better management of all types of risks - including the new risks associated with climate change and the spread of infectious diseases. In response, mining companies have to improve efficiency, introduce better risk management practices and ensure superior pricing 
arrangements through responding more quickly to demand patterns while looking for new uses for their production.

- Intelligent mining is happening. Technology is disrupting markets, mining, the future of work and leadership. What started as a "technology push" for mining companies two decades ago has now become a mining "pull". Mining companies have become very specific in their demand for technology systems that provide specific answers and solutions to their questions and problems. This global mining pull for relevant technology and skills for safe, intelligent mining is ushering in a new future for mining with a human-centered future of work.

- Mining skills-sets are changing. There is growing redundancy of old skills with a mounting need for new, more relevant skills-sets. This is a challenge for universities and skills providers, who must develop relevant curricula and keep up with the growing demand for future-ready graduates; they must also assist with re-skilling and up-skilling of the current workforce in mining at all levels, including leadership. This is causing universities and skills providers to re-imagine their qualifications, as well as how to deliver and certify them.

In summary, mining and its world of work is changing, and universities must keep up with the changing needs of the industry. There is a global switch to a mining industry defined by technology and innovation: an industry that is better, causes no harm, is ethical and is "clean". For such an industry, we need highly skilled workers with new skills-sets that are ready for mining's new world of work.

\section{World of work and mining}

Mining is changing in the twenty-first century and universities must prepare for it. Fig. 2 illustrates the traditional view of the world of work. This world of work is workplacecentred, a workplace which has specific tasks or deliverables. In order to complete these tasks, the workplace needs workers who have specific roles and tools for doing the work. Tools in the context include skills and resources to do the job effectively.

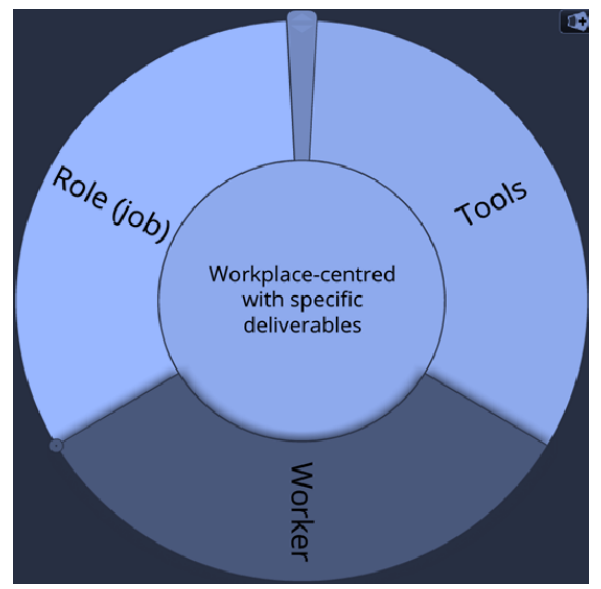

Fig. 2. Traditional view of a workplace-centred world of work (Goalscape image).

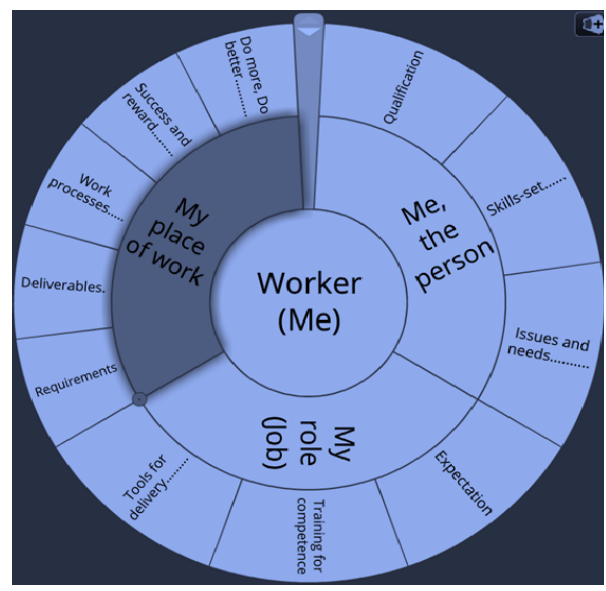

Fig. 3. Human-centred world of work (Goalscape image).

The traditional model has changed over time to become more human-centred. Fig. 3 illustrates this in its most basic form. In this world of work, the worker is in the centre, with the workplace around him or her. This is fundamentally different because it personalises the workplace. The worker then enters the world of work with a qualification and skills, in 
addition to his or her personal issues and needs. The worker still has a job to do, but brings personal expectations into the workplace - such as career development, employee benefits and additional training for competence and success in the workplace. In addition, the workers have specific requirements for performance, like minimum health and safety standards and organised labour (or trade union) representation to ensure fair treatment. It is also important to establish proper work processes for success. These become especially important when productivity is rewarded in some way.

When one extrapolates today's world of work, the fundamentals are similar for an office worker and a mineworker in the production zone. The outcome is decent work performed by skilled workers. Placing the person in the centre of this world of work raises some questions on the future of work, such as:

- What do workers want in and from their workspaces?

- What is the problem? What is expected of workers?

- What is success and how is it measured?

- What resources do they need to do well?

- Do the work processes lead to effective delivery?

- How can they get better at their jobs?

- Who are the clients and where does the job fit in the mining value chain?

- Is automation of the workflow possible and, more importantly, can a machine replace the worker?

- What will workers do when they lose their jobs? and

- What are the limits to technology and how much technology is needed to make the workplace better?

Ultimately, the answers to these questions have implications for the design of workplaces, the meaning of work, the division of labour and the certification of skills and qualifications. The lessons for mining are:

- The world is becoming more complex and less predictable;

- The waves of change must consider human needs, which means that change is required more regularly than in the past. As a result, business models and practices will also change more regularly;

- Qualifications and skills for competence are particularly important and are in fact a requirement for employment. This makes life-long (and self-) learning very important;

- Work environments must become more worker-friendly, safe and productive;

- Automation is happening and it is a threat to jobs;

- Ethics, law and policy must balance stakeholder interests; and

- Constant innovation and transformation is essential to make mining better.

Applying the world of work to mining must consider its drivers of change. It starts with changing the outdated perception that mining is dangerous, dirty and an industry of the past [8]. Despite the fact that change is often associated with a reduction in the number of jobs, change is also necessary to protect jobs. This can happen in two ways. The first is through job preservation, by saving current jobs when the lives of current orebodies are extended. Examples of extending job opportunities at existing mines are when it becomes possible to mine deeper areas, going back to areas that were left in the past because of some difficulty, economics or for safety reasons that no longer apply. The second manner in which change can protect jobs is to create jobs that were not there before - for example, starting new mines or expansion projects, and exploring remote areas that have potential for starting new mines. Other drivers of change include:

- To improve the health and safety environment for mine workers;

- To become more competitive by reducing prevailing operating costs;

- To improve productivity of assets and efficiency of operations. EY [9] estimates that digital effectiveness and data optimization can improve productivity by between 10 and 15 
per cent; and

- To stabilize return on investments.

It is also true that there are disadvantages associated with the introduction of technology in mining. These include fewer job opportunities at mines, redundancy of traditional skillssets with "lower-paid, lower-skilled, and less-educated workers ... at serious risk of obsolescence" [10]. This is significant. McKinsey estimates that 20 per cent of current jobs will be redundant by 2030 [11]. For mining, technology uptake is context-specific and affected by the size, age, depth and culture at the mine, in addition to the geological conditions, compatibility with existing designs, political ideologies and union bargaining strength. The impact of the 21st century on jobs and skills is profound. Fig. 4 illustrates how the change has affected the South African gold sector in recent times. South African mining faces many challenges apart from its cyclical market, increasing costs, mine safety and other issues. In the twentieth century, the hard times were "weathered" by introducing cost-saving activities and reducing supply. Such strategies normally worked to cause either survival or renewed profitability - made possible by the country's above-average resource quality and/or improved macroeconomics. However, this approach no longer seems to work and mineworkers continue to lose their jobs. This is despite temporary upswings in production as occurred in 2017 - Fig. 4.

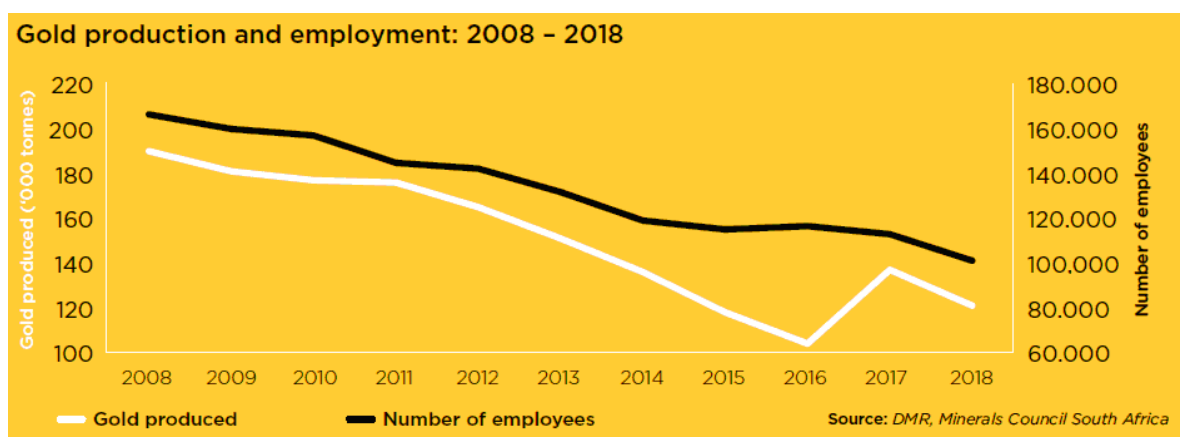

Fig. 4. South African gold mining production and employment. Source: MCSA [12].

To conclude, gold mining in South Africa is facing a systemic crisis. The downward trend started in the late twentieth century and is continuing in the 21 st century. Local gold production has collapsed from 605 tonnes in 1994 to 132 tonnes in 2018, despite South African gold reserves still ranking third internationally. The year 1994 is important in the South African context because it marks the start of democracy after the Apartheid era with post-1994 often referred to as "the new South Africa". In 1994, gold mines accounted for 392227 jobs and by 2018 this had fallen to 101085 - a loss of more than 290000 jobs over the period. Despite a collapse in output, gold mines still employ $22 \%$ of workers in the mining sector (453 543 in 2018). As jobs are lost in the formal market, illegal mining gains - to the detriment of the country. The illegal activity is evidence of sufficient reserves and the skills to extract at low cost.

This section demonstrated the scale of gold mining retrenchments and drop in production in South Africa's gold sector in the late 20th and early 21 st century. The change is significant and the problem systemic. What is clear is that outdated skills at formal operations are laid off at an unprecedented scale, and universities and skills providers must heed this development. They must align offerings to develop knowledge and skills matched with what is happening in the fourth industrial revolution in order to produce future-ready graduates as follows: 
- Understand that qualifications and skills must prepare graduates for jobs by addressing skills gaps with the right qualification that includes certification of a relevant skill for today;

- Workers demand low-risk, high-satisfaction workspaces. This also applies to mining and a design thinking approach can be applied to mine design to contextualize the production environment within the mining value chain;

- Job preservation and stakeholder trust is important. For this, the paradox of the impact of technology on jobs must be understood. For example, the paradox of fewer job opportunities because of technology, must be considered against more job opportunities at new mines made possible by technology breakthroughs;

- The law and policy for responsible mining must enable sustainable economic development and provide mining value chain opportunities in other economic sectors of the economy in order to stimulate inclusive growth; and

- Innovation and transformation are critical for a sustainable sector, but the change must be managed as a just transition going forward.

Technologically advanced mines are smarter, safer, leaner, more efficient and more sustainable. They need higher skilled jobs that are better-remunerated and digital, making mineworkers employable in other sectors of the economy. The skills for such jobs are transportable, allowing holders of such qualifications many opportunities elsewhere in the economy. This is the opportunity for university and skills providers, who should invest in market studies to establish where and what these opportunities are so that they can plan their education and training offerings accordingly.

\section{Impact on university programmes}

The impact of the fourth industrial revolution on universities is significant, with one measure of success: the employability of graduates. This has implications on curriculum design, where a partnership approach to teaching, learning and research is required at all levels of learning. Universities must understand that qualifications, skills and certification of competence must improve graduate employability. Learning content and teaching delivery for industry relevance must blend teaching and learning content and methods with teamwork and leadership principles. For this, universities require infrastructure for continuous learning, so the infrastructure must go beyond libraries to become collaborative spaces for big data self-learning. Such collaborative university programmes will rely on interdisciplinary research to tackle problems that are too large for a single-silo discipline. Finally, the ageing academic population is a global concern that requires deep transformation of professorial staff and an increased role for teaching assistants.

Leadership and teamwork principles must be integral with teaching, learning and assessment, and university staff must lose the traditional perception of "Teacher knows everything and students know nothing". Instead, one has to enable a situation where different role players and disciplines learn from each other, so there is learning between students and faculty, students and alumni, and industry and students. Identifying and attracting teaching talent will then have to consider more than just qualifications. Typical competencies for the 21 st century are:

- To design;

- To self-learn or to research;

- To create, manufacture or build;

- To install;

- To maintain and "preserve";

- To solve, change or improve;

- To lead; and

- To take calculated risks. 


\section{Considerations for universities offering mining qualifications}

Going forward, the big issues for mining programmes at universities are: firstly, to understand the skills market for mining graduates; secondly, to translate the skills market into a number so that graduate supply is in-sync with demand; thirdly, to assess the strength and sustainability of training, education and research institutions; fourthly, to understand the impact of technology on workers; and finally, to teach knowledge and skills that are required for 21 st century mining, but which are also transportable to other sectors of the economy. It is important to find a balance between foundational content (or knowledge) and proficiency (or skills) to prepare graduates for a job in today's job market - and be future-ready. The Society of Mining Professors (SOMP) recently published an excellent guideline on the considerations for updating mining engineering programmes, which can guide universities offering mining qualifications [13]. After considering everything in this article, the programme for mining professionals may look as follows:

- Personal development and preparing graduates for the world of work, with topics on managing oneself (personal mastery), work preparedness, workplace collaboration skills, green skills, ethics and value systems for the mining professional's exercise of responsible mining;

- The sciences, which include mathematical-, computer-, spatial and geoscience. These include the traditional content on geography, surveying, mapping and geology - in addition to new content on geographic information systems (GIS), computer processing of data, geostatistics and building information modelling. Mathematical science topics include mathematics, physics, statistics and cloud computing, while computer science topics include applied mathematics, programming, high-performance computing, coding, algorithm development, Blockchain and machine learning for artificial intelligence. New spatial data science topics include the internet of things and data security;

- Mining engineering with topics on the role of a mining engineer, types of mining, mining processes, application of general engineering principles to mining, mining methods, mine planning and design, mine geotechnical engineering, mine operations management; socio-environment factors, technical support services and technologies and mine modernization;

- Mining business and economics on investment, economic systems, mine finance, valuation and evaluation, metal and product sampling, accounting and reconciliation; and mineral resource management;

- Management and leadership, which include principles of management, mine management practices, resources-, change-, safety-, technology- and risk management [14]; and finally;

- Mining and mineral regulation content to cover the legal knowledge requirement for mining engineers.

\section{Conclusion and recommendation}

Mining in the 21 st century is changing and universities must develop future-ready graduates to build the industry. The impact the change associated with the fourth industrial revolution is profound and well documented [15]. It affects the number of jobs but also the skills and qualifications of graduates at professional, technician and artisan levels. The big mining skills issues for today are:

- Skills to keep the mine going;

- Refresher skills and up-skilling to keep jobs;

- To go beyond skills just for mining. It requires alignment with surrounding activity and the rest of the economy, to give the youth jobs and to empower communities; 
- Certification of vocational skills and alignment with tertiary institutions' education curricula; and

- Linking university curricula for articulation with leading national and international programs.

The way forward is to develop the skills to build people who will build the future. The call to action for universities is to understand the changes underway and bridge the gap with the right qualification for tomorrow, that includes a relevant skill for today. We must embrace technology as our friend and ally in everything we do in this human-centred future of work for mining.

I would like to expand my gratitude to Sibanye-Stillwater, whose support for the Wits Mining Institute is unparalleled. In addition, Mrs Ingrid Watson at the Wits Mining Institute (WMI) deserves acknowledgement for sharing ideas during the writing of this chapter.

\section{References}

1. Bondarenko, V., Kovalevs'ka, I., \& Ganushevych, K. (2014). Progressive technologies of coal, coalbed methane, and ores mining. London, United Kingdom: CRC Press, Taylor \& Francis Group. https://doi.org/10.1201/b17547

2. Pivnyak, G., Bondarenko, V., \& Kovalevska, I. (Eds.). (2015). New Developments in Mining Engineering 2015. London, United Kingdom: CRC Press, Taylor \& Francis Group. https://doi.org/10.1201/b19901

3. African Union (2009). African Mining Vision. Available at: www.africaminingvision.org/amv_resources/AMV/Africa_Mining_Vision_English.pdf

4. Cutifani, M. (2013). A critical imperative - innovation and a sustainable future. World Mining Congress. Montreal, Canada. Available from: https://southafrica.angloamerican.com/ /media/Files/A/Anglo-American-SouthAfrica/Attachments/media/presentation/mark-cutifani-speech-at-WMC.pdf

5. Cawood, F.T. (2018). Policy elements for twenty-first century African mining: Strengthening the existing African Mining Vision themes with cross-cutting subset. Journal of Science and Technology Policy Management, 9(1), 87-101. https://doi.org/10.1108/JSTPM-06-2017-0028

6. United Nations. The Sustainable Development Goals Report 2019. Available from https://unstats.un.org/sdgs/report/2019/The-Sustainable-Development-Goals-Report-2019.pdf

7. ICMM. Making a positive contribution to United Nations Sustainable Development Goals. Available from: https://www.icmm.com/en-gb/metals-and-minerals/making-a-positivecontribution $/ \mathrm{sdgs}$

8. Amin, C. (2018). Mining industry automation: Let the robots take our dangerous and dirty jobs. Structurial Engineers. Available from: https://www.createdigital.org.au/mining-industryautomation-robots/

9. EY (2019). Top 10 business risks and opportunities - 2020. EYGM Limited. Available from: https://www.ey.com/

10. IISD (2019). New Tech, New Deal: Technology impacts review. Intergovernmental Forum on Mining, Minerals, Metals and Sustainable Development. Manitoba, Canada: International Institute for Sustainable Development.

11. McKinsey. (2019). The future of Women at Work: Transitions in the age of automation. McKinsey Global Institute. Available from: www.mckinsey.com/mgi

12. Minerals Council South Africa. Facts and Figures Pocketbook 2018. Released September 2019. Available from: https://www.mineralscouncil.org.za/industry-news/media-releases/2019

13. SOMP 2019. Mines of the Future Version 1.0 Ed. Saydam S. Available from: https://MiningProfs.org 
14. Ross-Watt, D. (2019). Mining Engineering: Some perspectives on managing risk. Journal of the Southern African Institute of Mining and Metallurgy, 119(8), 24-26.

15. Schwab, K. (2018). Shaping the future of the fourth industrial revolution: A guide to building a better world. World Economic Forum. Portfolio Penguin. 